\title{
Les Jeans
}

Mûrs, vils

Elle porte

En styles

de toute sorte

Bleus ou gris

Qu'importe le tri--

Pourvu quil vît:

Crépuscule s'approchant 1a nuit

Voûte céleste

Bleue ou grise

I1 commence

I1 pique sa crise:

Argile toute moulée

Du désir refoulé

Tu troubles son âme Ainsi qu'une flamme Qui danse!

Dieu! la danse qui tourne en rond Tourne-toi chocolat qui se fond Tourne son soleil autour du monde Tourne timide ligne immonde Du cercle mûr de 1 a courbe ronde...

Cercle a jamais présent, Le regard $n$ 'est jamais absent! Hantes! Sois fascinante!

Incision!

Vision!

Dansez Djinns! dans ses jeans... 


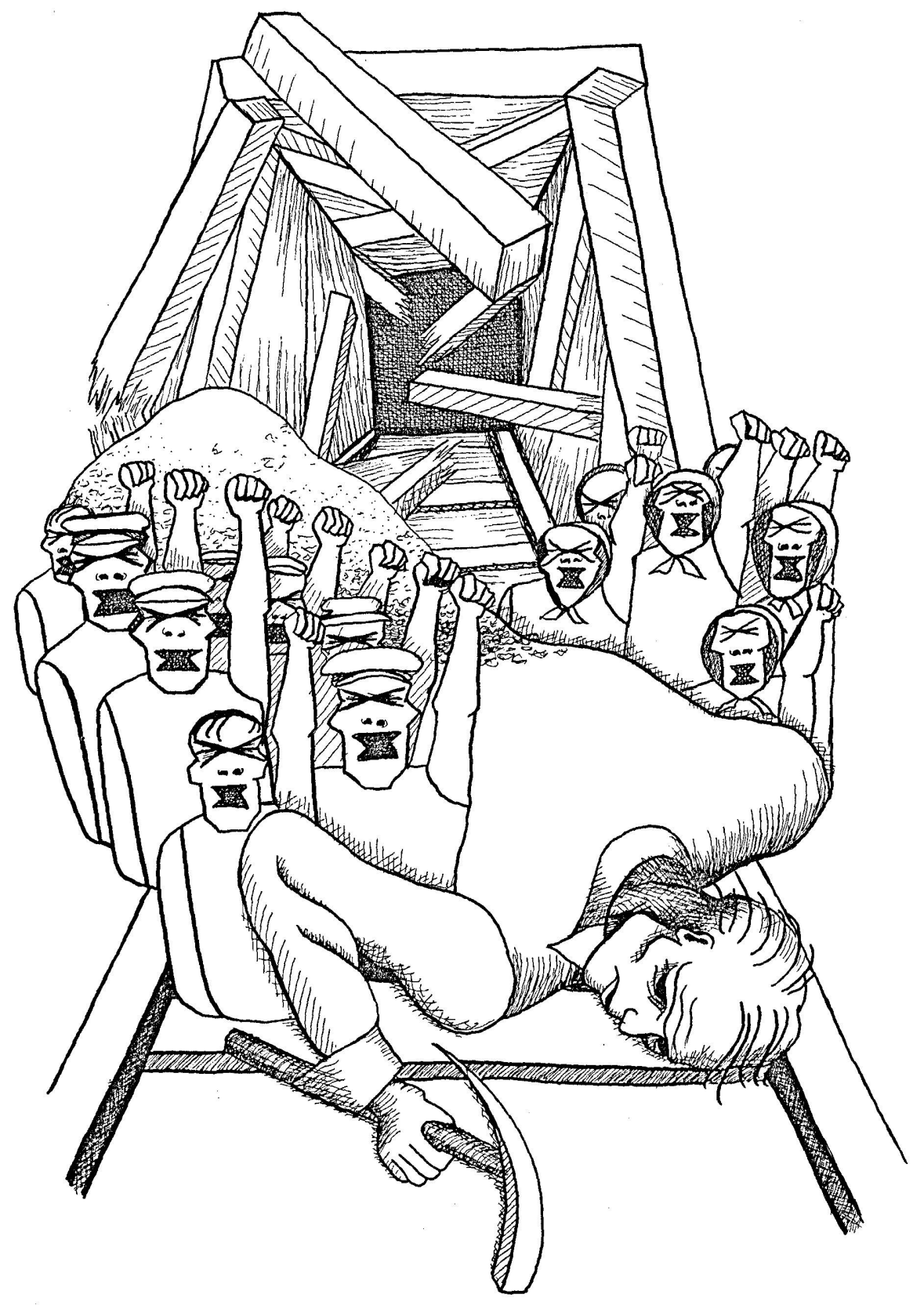

